\title{
Pengaruh Kepuasan Kerja Terhadap Motivasi Kerja dan Dampaknya Terhadap Kinerja Guru SMK Pasca Covid-19 di Aceh Timur
}

\author{
Jamali $^{1^{*}}$, Teuku Muana Refi ${ }^{2}$ \\ 1,2 Program Studi Keuangan dan Perbankan, Akademi Keuangan Perbankan \\ Nusantara, Kabupaten Aceh Timur, Provinsi Aceh, Indonesia
}

\begin{abstract}
Abstrak. Tujuan penelitian ini adalah untuk mengetabui: (1) Pengarub kepuasan kerja terhadap motivasi kerja, (2) Pengarub kepuasan kerja terhadap kinerja (3) Pengarub kepuasan kerja terhadap kinerja guru SMK pasca covid 19 di Kabupaten Aceh. Metode pengumpulan data dalam penilitian ini adalah surve, metode nonprobability dengan tehnik purposive sampling artinya dimana sampel dipilib berdasarkan karakteristiknya, alat analisa data menggunakan SPSS dengan jumlah sampel 120 responden. Hasil analisis menunjukekan babwa 1. tidak ada Pengaruh kepuasan kerja terhadap motivasi kerja guru hal ini dilihat dari probabilitas (sig) $=0,195$ karena nilai sig $<0,05$ koefisien korelasi tidak siknifikan dan t-tabel sebih besar dari pada t-hitung maka dapat diketahui bahwa motivasi kerja tidak dipengarubi oleh kepuasan kerja, 2 terdapat pengaruh kepuasan kerja Terdapat kinerja guru dan 3 terdapat Terdapat dampak motivasi kerja terhadap kinerja guru kepuasan kerja terhadap kinerja guru SMK pasca covid 19 di Kabupaten Aceh Timur.
\end{abstract}

Kata kunci: Kepuasan Kerja; Motivasi Kerja; Kinerja Guru.

\begin{abstract}
The purpose of this study was to determine: (1) The effect of job satisfaction on work motivation, (2) The effect of job satisfaction on performance (3) The effect of job satisfaction on the performance of post-covid 19 vocational high school teachers in Aceh Regency. The data collection method in this research is survey, nonprobability method with purposive sampling technique, which means that the sample is selected based on its characteristics, the data analysis tool uses SPSS with a sample of 120 respondents. The results of the analysis show that 1. there is no effect of job satisfaction on teacher work motivation, this is seen from the probability (sig) = 0.195 because the value of sig $<0.05$ the correlation coefficient is not significant and the $t$-table is greater than $t$ count, it can be seen that work motivation is not influenced by job satisfaction, 2 there is an effect of job satisfaction There is teacher performance and 3 there is an impact of work motivation on teacherperformance job satisfaction on the performance of post-covid 19 vocational high school teachers in East Aceh Regency.
\end{abstract}

Keywords: Job Satisfaction; Work Motivation; Teacher Performance. 


\section{Pendahuluan}

Pandemi Covid-19 di Indonesia pertama terjadi pada tanggal 2 Maret 2020 serta sudah menyebar ke 34 provinsi, menurut data "Indonesia confirms first cases of coronavirus". Bangkok Post (dalam bahasa Inggris). Pandemi telah membawa dampak yang sangat memprihatinkan bagi dunia pendidikan di seluruh Indonesia begitu juga pada Provinsi Aceh segala aspek terdampak pada kegiatan belajar mengajar (KBM) seperti penerapan pemebelajaran jarak jauh (PJJ) atau daring akan merubah pola ukur terhadap kinerja guru. Kinerja guru Sekolah Menengah Kejuruan (SMK) pasca covid 19 dilingkungan Kantor Cabang Dinas Pendidikan Kabupaten Aceh Timur perlu mendapatkan perhatian serius. Maka dalam hal ini diperlukan sebuah usaha yang berkelanjutan dalam membangun sumber daya manusia yang berkualitas dalam hal ini adalah tenaga pendidik sesuai dengan standar yang telah ditentukan dan telah disepakati bersama secara nasional. Kinerja merupakan suatu kegiatan yang dilakukan untuk melaksanakan, menyelesaikan tugas dan tanggung jawab sesuai dengan harapan dan tujuan yang telah ditetapkan (Supardi, 2014).

Secara teoritis yang didasarkan pada sejumlah penelitian sebelumnya, terdapat sejumlah faktor yang dapat mempengaruhi motivasi kerja dan kinerja guru pada suatu lembaga pendidikan diantaranya motivasi dan kepuasan kerja mempunyai pengaruh dalam meningkatkan kinerja guru. Seorang Guru yang profesional biasanya merupakan hasil dari penggabungan dari multi kompetensi guru, dapat berupa seperangkat pengetahuan, keterampilan, dan perilaku yang harus dimiliki, dihayati, dan dikuasai oleh guru dalam menjalankan tugas keprofesionalannya pada masa covid 19. Berdasarkan latar belakang masalah penelitian penulis merumuskan tujuan yaitu untuk mengetahui:

1. Bagaimana Pengaruh Kepuasan Kerja terhadap Motivasi Kerja Guru SMK pasca covid 19 di Kabupaten Aceh Timur.

2. Bagaimana pengaruh kepuasan kerja terhadap kinerja guru SMK pasca covid 19 di Kabupaten Aceh Timur.
3. Bagaimana dampak motivasi kerja terhadap kinerja guru SMK pasca covid 19 di Kabupaten Aceh Timur

Selama ini kajian empiris mengenai Motivasi Kerja dan Kinerja Guru dalam meningkatan keprofesionalitasnya pada lembaga pendidikan yang ada di kabupaten Aceh Timur belum banyak dilakukan oleh para peneliti. Kinerja Guru sangat diperlukan untuk meningkatkan kompetensi siswa sebagai subjek penerima layanan jasa pendidikan yang sangat penting untuk mewujudkan pembangunan secara menyeluruh dibidang Pendidikan selama terjadinya kasus Covid 19 di Aceh Timur telah membawa dampak terhadap kinerja guru secara umum.

\section{Tinjauan Literatur}

\section{Kepuasan Kerja}

Kepuasan kerja didefinisikan sebagai sejauh mana seorang karyawan merasa termotivasi, puas dan dengan pekerjaannya (Idiegbeyan-Ose et al., 2019; Basyir, 2020). Kepuasan kerja terjadi ketika seorang karyawan merasa memiliki stabilitas pekerjaan, pertumbuhan karir dan keseimbangan kehidupan kerja yang nyaman (Amri, 2015; Aruldoss, Kowalski, \& Parayitam, 2020). Ini menyiratkan bahwa karyawan tersebut memiliki kepuasan di tempat kerja karena pekerjaan memenuhi harapan individu. Seorang karyawan yang puas selalu penting bagi sebuah organisasi karena bertujuan untuk memberikan yang terbaik dari kemampuan mereka (Ekhsan, 2019; Paais \& Pattiruhu, 2020). Setiap karyawan menginginkan pertumbuhan karir yang kuat dan keseimbangan kehidupan kerja di tempat kerja (Farmiati \& Ismail, 2021; Farrington, 2020). Jika seorang karyawan merasa senang dengan perusahaan dan pekerjaan mereka, maka karyawan tersebut berusaha untuk memberikan kembali kepada perusahaan dengan segala upaya mereka.

Pentingnya kepuasan kerja dapat dilihat dari dua perspektif, yaitu:

1. Bagi Karyawan

Kepuasan kerja dari perspektif karyawan adalah untuk mendapatkan gaji kotor yang baik, memiliki stabilitas pekerjaan, memiliki pertumbuhan karir yang stabil, mendapatkan penghargaan dan pengakuan 
dan terus-menerus memiliki peluang baru.

2. Bagi Pengusaha

Bagi Pengusaha, kepuasan kerja bagi seorang karyawan merupakan aspek penting untuk mendapatkan yang terbaik dari mereka. Karyawan yang puas selalu memberikan kontribusi lebih kepada perusahaan, membantu mengendalikan gesekan dan membantu perusahaan untuk terus tumbuh. Pengusaha perlu memastikan deskripsi pekerjaan yang baik untuk menarik karyawan dan terusmenerus memberikan kesempatan kepada individu untuk belajar dan tumbuh.

Dampak positif dari kepuasan kerja antara lain:

1. Memiliki efisiensi karyawan di tempat kerja jika mereka puas dengan pekerjaan.

2. Loyalitas karyawan yang lebih tinggi mengarah pada komitmen yang lebih besar.

3. Kepuasan kerja karyawan pada akhirnya menghasilkan keuntungan yang lebih tinggi bagi perusahaan.

4. Retensi karyawan yang tinggi dimungkinkan jika karyawan senang.

Faktor kepuasan kerja berkaitan dengan psikologi seorang karyawan (Al-Ali et al., 2019). Karyawan yang bahagia dan puas di suatu pekerjaan selalu termotivasi untuk berkontribusi lebih banyak (Geisler, Berthelsen, \& Muhonen, 2019; Phuong \& Vinh, 2020). Di sisi lain, karyawan yang tidak puas menjadi lesu, melakukan kesalahan dan menjadi beban bagi perusahaan. Elemen dan faktor yang berkontribusi terhadap kepuasan kerja adalah:

1. Kompensasi dan Kondisi kerja

2. Keseimbangan kehidupan kerja

3. Penghormatan dan Pengakuan

4. Keamanan kerja

5. Tantangan

6. Pertumbuhan Karir (Irabor \& Okolie, 2019; TS 2019).

Kepuasan kerja pada lembaga pendidikan dapat dipengaruhi oleh sejumlah faktor. Dalam kajian ini, predictor variable kepuasan kerja dibatasi hanya pada motivasi kerja dan kinerja guru di lingkungan SMK Kabupaten Aceh Timur. Hubungan antara variabel-variabel tersebut dijelaskan pada sub-bab selanjutnya.

\section{Motivasi Kerja}

Konsep motivasi memiliki posisi sentral di seluruh bidang psikologi. Motivasi adalah tentang pilihan di mana menghabiskan energi dan bagaimana kita memprioritaskan pilihanpilihan yang sangat relevan di dunia kerja (Sarboini \& Mariati, 2020; Sarboini \& Yanti, 2018). Menjadi sangat termotivasi di tempat kerja berarti telah berusaha lebih keras untuk melakukan yang terbaik (Rizal, 2019). Terkadang dimotivasi oleh faktor eksternal seperti berapa banyak dibayar, manfaat yang diterima melalui pekerjaan, atau apakah karyawan menerima pengakuan dari penyelia atau umpan balik positif. Di sisi lain, faktor internal memotivasi karyawan, seperti seberapa besar menikmati apa yang di lakukan atau seberapa penting kepercayaan karyawan bahwa pekerjaan itu sangat penting bagi perusahaan. Motivasi kerja memiliki dampak langsung pada kinerja karyawan. Beberapa organisasi psikolog telah mencatat bahwa kinerja karyawan dipengaruhi oleh; 1) Kemampuan mereka untuk melakukan pekerjaan, dan 2) Motivasi mereka untuk sukses.

Motivasi kerja bisa diartikan sebagai alasan yang dimiliki pekerja untuk berperilaku atau bertindak terhadap sesuatu yang di butuhkan dan atau dipedulikan (Duha, 2020). Motivasi adalah bagaimana seseorang menyelesaikan sesuatu ketika memiliki tujuan yang di pedulikan (Abadiyah, Eliyana, \& Sridadi, 2020). Motivasi adalah semua faktor yang mendorong individu untuk berkomitmen dan tertarik untuk melakukan sesuatu dari waktu ke waktu (Jumaboyeva \& Daminova, 2019). Perasaan minat yang kuat dan keinginan untuk bertindak bisa bersifat sementara. Ini memberi tahu bahwa seseorang menuju ke arah yang benar, tetapi berbagai aspek yang mendorong untuk merasa seperti itu adalah aspek yang akan mempertahankan tindakan dari pekerjaan. Faktor-faktor ini bisa berbeda dari satu orang ke orang lain.

Motivasi sangat terkait dengan makna yang di berikan pada apa yang di lakukan. Sering kali makna itu tidak terkait dengan hasil langsung dari pekerjaan atau dengan tugas tertentu. Maka perlu menetapkan makna berdasarkan hasil yang lebih besar atau tujuan yang lebih besar 
untuk menilai sesuatu dalam pekerjaan. Ketika karyawan tidak merasa berkomitmen atau terhubung dengan bagian dari sesuatu yang penting, ketika mereka tidak dapat berhubungan dengan misi perusahaan atau hanya tidak dapat melihat pentingnya peran mereka dalam skala yang lebih besar, mereka sering kehilangan motivasi. 70 persen pekerja di Amerika mengatakan mereka terjebak dalam pekerjaan di mana mereka benar-benar tidak terlibat dan 30 persen dari kelompok itu secara aktif membenci pekerjaan mereka.

Kebencian terhadap pekerjaan setidaknya merupakan perasaan yang kuat dan dapat memotivasi seseorang untuk akhirnya mengambil tindakan. Sebagian karyawan mungkin dapat meningkatkan dan mendorong perbaikan dalam situasi atau dinamika yang menjadi tidak bisa dijalankan. Kebencian dari pekerjaan juga memaksa karyawan untuk jujur tentang ketidakcocokan dan ketidaksejajaran dengan organisasi dan beralih ke pekerjaan dan tempat kerja yang lebih sesuai dengan nilai dan aspirasi mereka. Beberapa demotivator yang paling umum di tempat kerja cukup biasa dan bahkan sepele, tetapi sejauh mana menilai karyawan terhadap motivasi kerja diperlukan kajian dan analisis yang lebih besar dalam melihat tujuan, makna, dan nilai dalam suatu pekerjaan.

\section{Kinerja Guru}

Guru memiliki tugas utama dalam mendidik, mengajar, mengarahkan, membimbing, menilai, melatih dan melakukan evaluasi pada siswa sehingga dapat dikatakan sebagai pendidik yang professional dalam melaksanakan tugas. Selain itu kewajiban seorang guru yang profesional yaitu merencanakan pembelajaran, menjalankan proses pembelajaran yang bermutu, dan menilai serta mengevaluasi hasil pembelajaran. Lalu ditegaskan kembali bahwa tugas pokok dari seorang guru adalah merencanakan pembelajaran, melaksanakan pembelajaran, menilai hasil pembelajaran, membimbing dan melatih siswa (Priansa, 2018).

Sedangkan menurut Saud (2013) menjelaskan bahwa "kinerja guru dalam proses mengajar harus memiliki kompetensi yang terdiri dari: a) merencanakan proses pembelajaran, b) melaksanakan dan memimpin atau mengelola proses belajar, dan c) menilai kemajuan proses belajar mengajar".

Kinerja guru dalam mewujudkan pendidikan holistik dapat dilihat dari bagaimana guru mempersiapkan, melaksanakan, dan mengevaluasi proses pembelajaran atau pengetahuan pedagogiknya (Bruggeman et al., 2021). Menurut Sutiana \& Mulyasa (2019) Faktor-faktor yang mempengaruhi kinerja guru adalah; 1) Faktor personal/individu, 2) Faktor kepemimpinan, 3) Faktor tim, 4) Faktor sistem, dan 5) Faktor kontekstual (situasional). Menurut Mathis \& Jackson (2006) beberapa faktor yang memengaruhi kinerja, yaitu; 1) Kemampuan, 2) Motivasi, 3) Dukungan yang diterima, 4) Keberadaan pekerjaan yang dilakukan, dan 5) Hubungan dengan organisasi. Menurut Mulyasa dkk (2020) faktor-faktor yang dapat meningkatkan kinerja guru, yaitu; 1) Dorongan untuk bekerja, 2) Tanggung jawab terhadap tugas, 3) Minat terhadap tugas, 4) Penghargaan terhadap tugas, 5) Peluang untuk berkembang, 6) Perhatian dari kepala sekolah, 7) Hubungan interpersonal dengan sesama guru, 8) MGMP dan KKG, 9) Kelompok diskusi terbimbing, dan 10) Layanan perpustakaan.

\section{Metodologi Penelitian}

\section{Lokasi, Objek Penelitian, Populasi dan Sampel}

Penelitian ini dilakukan pada 12 SMK dilingkup Pemerintah Kabupaten Aceh Timur. Objek Penelitian ini dilakukan untuk memperoleh data-data yang berkaitan dengan objek penelitian yaitu pengaruh kepuasan kerja terhadap motivasi kerja dan dampaknya terhadap kinerja guru SMK pasca covid 19. Penelitian ini memiliki tiga variabel yaitu Variabel bebas (X) dalam penelitian ini adalah kepuasan kerja sedangkan variabel terikat $(\mathrm{Y})$ dalam penelitian ini adalah motivasi kerja dan variabel terikat $(Z)$ dalam penelitian ini adalah kinerja guru. Populasi penelitian adalah seluruh guru pada 12 SMK yang dijadikan unit analisis. Sampel setiap SMK diambil 10 orang guru, dengan jumlah sampel secara keseluruhan sebanyak 120 orang guru. 


\section{Operasional Variabel}

Variabel yang dioperasionalkan dalam penelitian ini terdiri dari kepuasan kerja, motivasi kerja dan Kinerja Guru SMK. Pengukuran kepuasan kerja diadopsi dari Afandi (2018) mengunakan 5 indikator yang meliputi pekerjaan, upah, promosi, pengawas, dan rekan kerja. Pengukuran motivasi kerja mengacu Afandi, (2018) menggunakan 6 indikator yaitu: balas jasa, kondisi kerja, fasilitas kerja, prestasi kerja, pengakuan dari atasan dan pekerjaan itu sendiri. Selanjutnya pengukuran kinerja guru mengacu pada pendapat Supardi, (2014) dengan mengunakan 6 indikator yaitu kemampuan menyusun rencana pembelajaran, kemampuan melaksanakan pembelajaran, kemampuan melaksanakan hubungan antar pribadi, kemampuan melaksanakan penilaian hasil belajar, kemampuan melaksanakan program pengayaan, dan kemampuan melaksanakan program remedial.

\section{Teknik Pengumpulan Data dan Skala Pengukuran}

Pengumpulan data dilakukan dengan cara mendistribusikan kuesioner kepada para guru dilingkungan Kantor Cabang Dinas Aceh Timur. Kuesioner tersebut pernyataan/pernyataan berkaitan dengan indikator-indikator kepuasan kerja, motivasi kerja dan kinerja guru. Masing-masing pernyataan disediakan alternatif pilihan jawaban dalam bentuk tingkat kesetujuan. Setiap guru diminta untuk memberikan check list $(\sqrt{ })$ pada alternatif pilihan jawaban yang mereka anggap paling sesuai dengan kondisi riil yang mereka rasakan/ketahui. Skala pengukuran yang digunakan dalam penelitian ini adalah skala Likert (Likert scale) dengan bobot berkisar antara 1 sampai 5 , dengan ketentuan $1=$ sangat tidak setuju, $2=$ tidak setuju, $3=$ kurang setuju, $4=$ setuju dan $5=$ sangat setuju.

\section{Desain Penelitian dan Alat Analisis Data}

Penelitian ini menggunakan pendekatan kuantitatif dengan desain kausalitas, yakni menguji dan menganalisis pengaruh antara kepuasan kerja dengan dua outcome variable meliputi motivasi kerja dan kinerja guru. Dalam proses pengolahannya dilakukan dengan menggunakan software SPSS V26 Untuk menguji tingkat validitas instrumen dalam penelitian ini digunakan teknik analisis Koefisien Korelasi Produk-Moment Pearson (Pearson Product-Moment).

\section{Hasil dan Pembahasan}

\section{Karakteristik Responden}

Hasil penelitian terhadap 120 responden yang diteliti dalam penelitian ini, memberikan gambaran mengenai karakteristik responden berdasarkan jenis kelamin sebagaimana terlihat dalam tabel di bawah ini:

Tabel 1. Deskripsi Responden Berdasarkan Jenis Kelamin

\begin{tabular}{lcc}
\hline \multicolumn{1}{c}{ Jenis } & $\begin{array}{c}\text { Jumlah } \\
\text { (Orang) }\end{array}$ & $\begin{array}{c}\text { Persentase } \\
\mathbf{( \% )}\end{array}$ \\
\hline Laki-laki & 109 & 90,8 \\
Perempuan & 11 & 9,2 \\
Total & 120 & 100,0 \\
\hline
\end{tabular}

Berdasarkan data yang disajikan dalam tabel di atas tampak bahwa sebesar 109 orang (90,8\%) di antaranya adalah responden laki-laki, sedangkan responden perempuan berjumlah 11 orang $(9,2 \%)$. Dalam penelitian ini tidak dijelaskan tentang perbedaan persepsi tentang variabel penelitian antara responden laki-laki dan perempuan karena persepsi yang diharapkan adalah secara keseluruhan. Jadi, tidak ada perbedaan antara responden laki-laki dan perempuan. Karakteristik responden selanjutnya adalah mengenai usia responden, seperti dijelaskan dalam tabel dibawah ini:

Tabel 2. Usia Responden

\begin{tabular}{lll}
\hline $\begin{array}{c}\text { Usia } \\
\text { (Tahun) }\end{array}$ & \multicolumn{1}{c}{$\begin{array}{c}\text { Jumlah } \\
\text { (Responden) }\end{array}$} & \multicolumn{1}{c}{$\begin{array}{c}\text { Persentase } \\
(\mathbf{\%})\end{array}$} \\
\hline $20-29$ tahun & 4 & 3,3 \\
$30-39$ & 28 & 23,3 \\
$>40$ & 88 & 73,3 \\
\hline
\end{tabular}

Selanjutnya jika ditinjau dari latar belakang usia, Responden dalam penelitian ini, berumur antara 20 - 29 tahun tahun sebanyak 4 orang $(3,3 \%)$, sebanyak 28 orang $(23,3 \%)$ berumur di $30-39$ tahun, dan sebanyak 88 orang $(73,3 \%)$ berumur $<40$ tahun. Dengan demikian responden dalam penelitian ini sebagian besar berumur antara $<40$ sebanyak 88 orang $(73,3 \%)$. 
Tabel 3. Deskripsi responden jika ditinjau dari pendidikannya

\begin{tabular}{lll}
\hline $\begin{array}{c}\text { Status } \\
\text { Pendidikan }\end{array}$ & $\begin{array}{c}\text { Jumlah } \\
\text { (Responden) }\end{array}$ & $\begin{array}{c}\text { Persentase } \\
\mathbf{( \% )}\end{array}$ \\
\hline S1 & 98 & $81,7 \%$ \\
S2 & 22 & $18,3 \%$ \\
\hline
\end{tabular}

Berdasarkan data yang disajikan dalam tabel di atas tampak bahwa sebanyak 98 orang responden $(81,7 \%)$ pendidikan terakhir $\mathrm{S} 1$, sebanyak 22 responden (18,3\%) berpendidikan S2.

\section{Uji Validitas dan Reliabilitas Alat Ukur}

Pengujian validitas tiap butir digunakan analisis item, yaitu mengkorelasikan skor tiap butir dengan skor total yang merupakan jumlah tiap skor butir (corrected item total correlation) yang penyelesaiannya dilakukan dengan menggunakan program SPSS 20.0. Uji validitas dilakukan dengan membandingkan antara $r$ hitung dengan r-tabel, di mana r-tabel pada nilai kritis 5\% yaitu 0,178 (lihat tabel nilai kritis korelasi r Product-Moment untuk n-2 $=120$ pada lampiran output SPSS), sehingga jika nilai corrected item total correlation/ t-hitung lebih besar dari r-tabel, hal ini berarti data yang diperoleh adalah valid dan dapat dipergunakan untuk penelitian.

Sedangkan untuk menilai realibilitas atau kehandalan kuesioner yang digunakan, maka dalam penelitian ini digunakan uji realibilitas berdasarkan Cronbach's Alpha yang lazim digunakan untuk pengujian kuesioner dalam penelitian ilmu sosial. Pengujian reliabilitas dimaksudkan untuk mengetahui sejauh mana hasil pengukuran tetap konsisten juga jika dilakukan secara statistik yaitu dengan menghitung besarnya Cronbach's Alpha dengan bantuan program SPSS 20.0. Menurut Malhotra (2005) koefisien Cronbach's Alpha yang dapat diterima adalah di atas 0,60 .

Berdasarkan hasil uji validitas dan reliabilitas variabel korelasi kualitas produk yang disajikan dalam tabel 4.6 tampak bahwa, masing-masing item pertanyaan dalam indikator memiliki nilai corrected item total correlation atau koefisien validitas (r-hitung) lebih besar dari 0,359. Dengan demikian dapat disimpulkan bahwa, masing-masing item pertanyaan dalam indikator tersebut adalah valid. Untuk lebih jelasnya dapat dilihat pada tabel 4 berikut ini.

Tabel 4. Hasil Uji Validitas dan Reliabilitas Indikator Korelasi Kepuasan Kerja

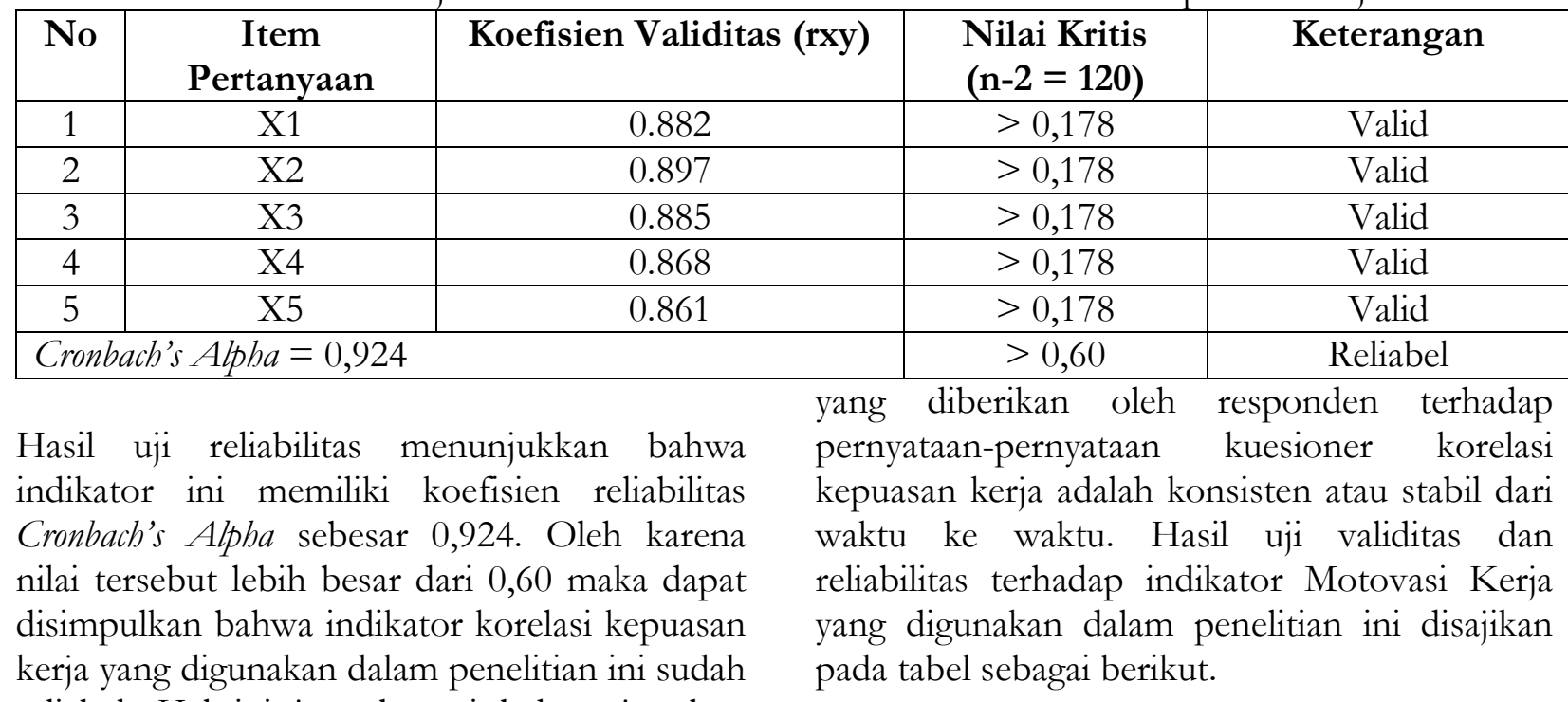


Tabel 5. Hasil Uji Validitas dan Reliabilitas Indikator Korelasi Motivasi Kerja

\begin{tabular}{|c|l|c|c|c|}
\hline No & $\begin{array}{l}\text { Item } \\
\text { Pertanyaan }\end{array}$ & Koefisien Validitas (rxy) & $\begin{array}{l}\text { Nilai Kritis } \\
(\mathbf{n}-2=120)\end{array}$ & Keterangan \\
\hline 1 & Y1 & 0,853 & $>0,178$ & Valid \\
\hline 2 & Y2 & 0,875 & $>0,178$ & Valid \\
\hline 3 & Y3 & 0,840 & $>0,178$ & Valid \\
\hline 4 & Y4 & 0,833 & $>0,178$ & Valid \\
\hline 5 & Y5 & 0,865 & $>0,178$ & Valid \\
\hline 6 & Y6 & 0,851 & $>0,178$ & Valid \\
\hline \multicolumn{2}{|l|}{ Cronbach's Alpha $=0,925$} & & $>0,60$ & Reliabel \\
\hline
\end{tabular}

Berdasarkan hasil uji validitas dan reliabilitas yang disajikan dalam tabel di atas tampak bahwa, masing-masing item pertanyaan dalam indikator motivasi kerja memiliki nilai koefisien validitas lebih besar dari 0,178. Dengan demikian dapat disimpulkan bahwa, masingmasing item pertanyaan dalam indikator tersebut adalah valid. Hal ini juga berarti bahwa kuesioner motivasi kerja yang dibuat mampu untuk mengukur dan mengungkapkan motivasi kerja.
Hasil uji reliabilitas menunjukkan bahwa indikator ini memiliki koefisien reliabilitas Cronbach's Alpha sebesar 0,925. Oleh karena nilai tersebut lebih besar dari 0,60 maka dapat disimpulkan bahwa indikator motivasi kerja yang digunakan dalam penelitian ini reliabel. Hal ini juga berarti bahwa jawaban yang diberikan oleh responden terhadap pernyataanpernyataan kuesioner motivasi kerja adalah konsisten atau stabil dari waktu ke waktu.

Hasil uji validitas dan reliabilitas terhadap indikator kinerja guru yang digunakan dalam penelitian ini disajikan pada tabel sebagai berikut

Tabel 6. Hasil Uji Validitas dan Reliabilitas Indikator Korelasi Kinerja Guru

\begin{tabular}{|c|c|c|c|c|}
\hline No & Item Pertanyaan & Koefisien Validitas (rxy) & $\begin{array}{c}\text { Nilai Kritis } \\
(\mathbf{n - 2}=\mathbf{1 2 0})\end{array}$ & Keterangan \\
\hline 1 & Z1 & 0,843 & $>0,178$ & Valid \\
\hline 2 & Z2 & 0,895 & $>0,178$ & Valid \\
\hline 3 & Z3 & 0,882 & $>0,178$ & Valid \\
\hline 4 & Z4 & 0,865 & $>0,178$ & Valid \\
\hline 5 & Z5 & 0,871 & $>0,178$ & Valid \\
\hline 6 & Z6 & 0,898 & $>0,178$ & Valid \\
\hline \multicolumn{2}{|l|}{ Cronbach's Aøha $=0,939$} & & $>0,60$ & Reliabel \\
\hline
\end{tabular}

Berdasarkan hasil uji validitas dan reliabilitas yang disajikan dalam tabel di atas tampak bahwa, masing-masing item pertanyaan dalam indikator kinerja guru memiliki nilai koefisien validitas lebih besar dari 0,178. Dengan demikian dapat disimpulkan bahwa, masingmasing item pertanyaan dalam indikator tersebut adalah valid. Hal ini juga berarti bahwa kuesioner kinerja guru yang dibuat mampu untuk mengukur dan mengungkapkan variabel kinerja guru.
Hasil uji reliabilitas menunjukkan bahwa indikator ini memiliki koefisien reliabilitas Cronbach's Alpha sebesar 0,939. Oleh karena nilai tersebut lebih besar dari 0,60 maka dapat disimpulkan bahwa indikator kinerja guru yang digunakan dalam penelitian ini reliabel atau konsisten dari waktu ke waktu. 


\section{Pengujian Hipotesis}

Hipotesis yang akan diuji adalah sebagai berikut:

Tabel 7. Hasil Pengujian Coefficient

\section{Coefficients $^{\mathrm{a}}$}

\begin{tabular}{|c|c|c|c|c|c|c|}
\hline \multirow[b]{2}{*}{ Mod } & & \multicolumn{2}{|c|}{ Unstandardized Coefficients } & \multirow{2}{*}{$\begin{array}{c}\text { Standardized } \\
\text { Coefficients } \\
\text { Beta }\end{array}$} & \multirow[b]{2}{*}{$t$} & \multirow[b]{2}{*}{ Sig. } \\
\hline & & B & Std. Error & & & \\
\hline \multirow[t]{3}{*}{1} & (Constant) &,- 639 &, 698 & &,- 916 & ,362 \\
\hline & $x$ & ,199 &, 153 &, 158 & 1,304 &, 195 \\
\hline & $Y$ &, 860 & ,131 &, 797 & 6,580 &, 000 \\
\hline
\end{tabular}

a. Dependent Variable: Z

T- table sebesar 1,980

Hipotesis 1

$\mathrm{Ha}=$ Terdapat Pengaruh Kepuasan Kerja terhadap Motivasi Kerja Guru SMK pasca covid 19 di Kabupaten Aceh Timur

$\mathrm{Ho}=$ Tidak terdapat Pengaruh Kepuasan Kerja terhadap Motivasi Kerja Guru SMK pasca covid 19 di Kabupaten Aceh Timur

Dari nilai probabilitas (sig) $=0,195$ karena nilai sig $<0,05$ dan t-tabel lebih besar dari pada thitung maka keputusannya adalah $\mathrm{H} 0$ diterima dan $\mathrm{Ha}$ di tolak artinya koefisien korelasi tidak siknifikan maka tidak terdapat Pengaruh kepuasan kerja terhadap kinerja guru SMK pasca covid 19 di Kabupaten Aceh Timur.

T- table sebesar 1,980

Hipotesis 2

$\mathrm{Ha}=$ Terdapat Pengaruh kepuasan kerja terhadap kinerja guru SMK pasca covid 19 di Kabupaten Aceh Timur
Ho $=$ Tidak Terdapat Pengaruh kepuasan kerja terhadap kinerja guru SMK pasca covid 19 di Kabupaten Aceh Timur

Dari nilai t-tabel 1,980 dan t-hitung lebih besar yaitu 6,580 dari t-tabel dan nilai probabilitas (sig) $=0,000$ karena nilai sig $<0,05$ lehih becil dari maka keputusannya adalah $\mathrm{Ha}$ diterima dan Ho di tolak artinya koefisien korelasi siknifikan maka Terdapat Pengaruh kepuasan kerja terhadap kinerja guru SMK pasca covid 19 di Kabupaten Aceh Timur.

Hipotesis 3

$\mathrm{Ha}=$ Terdapat dampak motivasi kerja terhadap kinerja guru pada SMK pasca covid 19 di Kabupaten Aceh Timur

$\mathrm{Ho}=$ Tidak Terdapat dampak motivasi kerja terhadap kinerja guru pada SMK pasca covid 19 di Kabupaten Aceh Timur

Tabel 8. Hasil Pengujian ANOVA

ANOVA $^{\text {a }}$

\begin{tabular}{ll|r|r|r|r|r}
\multirow{2}{*}{ Model } & \multicolumn{1}{c}{$\begin{array}{c}\text { Sum of } \\
\text { Squares }\end{array}$} & df & Mean Square & \multicolumn{1}{c}{ F } & \multicolumn{1}{c}{ Sig. } \\
\hline \multirow{2}{*}{1} & Regression & 4055,425 & 2 & 2027,713 & 550,521 &, $000^{\text {b }}$ \\
\cline { 2 - 8 } & Residual & 430,941 & 117 & 3,683 & & \\
\cline { 2 - 8 } & Total & 4486,367 & 119 & & & \\
\hline
\end{tabular}

a. Dependent Variable: Z

b. Predictors: (Constant), Y,X

50 | Jurnal Ekonomi dan Manajemen Teknologi Vol. 6 | No. 1 | 2022 
Dari tabel ANOVA diatas maka diperoleh nilai F sebesar 550,521dengan nilai probabilitas (sig) $=0,000$ karena nilai sig $<0,05$ maka keputusannya adalah $\mathrm{H} 0$ ditolak dan $\mathrm{Ha}$ di terima maka Terdapat dampak motivasi kerja terhadap kinerja guru pada SMK pasca covid 19 di Kabupaten Aceh Timur.

\section{Kesimpulan}

Dari hasil penelitian maka dapat disimpukan sebagai berikut

1. Tidak terdapat Pengaruh kepuasan kerja terhadap motivasi kerja guru SMK pasca covid 19 di Kabupaten Aceh Timur Dari nilai probabilitas (sig) $=0,195$ karena nilai sig $<0,05$ koefisien korelasi tidak siknifikan hal dengan demikian dapat diketahui bahwa motivasi kerja tidak dipengaruhi oleh kepuasan kerja hal ini dilihat dari perolehan nilai probabilitas lebih kecil dari nilai signifikansi yaitu 0,195

2. Terdapat Pengaruh kepuasan kerja terhadap kinerja guru SMK pasca covid 19 di Kabupaten Aceh Timur Dari nilai ttabel diatas dapat diketahui bahwa probabilitas (sig) $=0,000$ karena nilai sig < 0,05 lehih becil dari nilai probabilitas maka kinerja guru dipengaruhi oleh kepuasan kerja

3. Terdapat Pengaruh kepuasan kerja terhadap kinerja guru SMK pasca covid 19 di Kabupaten Aceh Timur Dari nilai ttabel diatas dapat diketahui bahwa probabilitas (sig) $=0,000$ karena nilai sig < 0,05 lehih becil dari maka keputusannya adalah $\mathrm{Ha}$ diterima dan Ho di tolak artinya koefisien korelasi siknifikan.

\section{Ucapan Terima Kasih}

Ucapan terima kasih kepada Direktorat Riset dan Pengabdian Masyarakat sebagai penyandang dana Penelitian Tahun Anggaran 2021, dan LLDIKTI Wilayah XIII Provinsi Aceh yang telah memberikan motivasi kepada peneliti. Tak lupa pula kepada LPPM Akademi Keuangan Perbankan Nusantara yang telah memberikan fasilitas serta dukungan baik moril dan materil sehingga penelitian ini terlaksana sebagaimana dengan harapan tim peneliti.

\section{Daftar Pustaka}

Abadiyah, R., Eliyana, A., \& Sridadi, A. R. (2020). Motivation, leadership, supply chain management toward employee green behavior with organizational culture as a mediator variable. International Journal of Supply Chain Management, 9(3), 981-989.

Afandi, P. (2018). Manajemen Sumber Daya Manusia (Teori, Konsep dan Indikator). Riau: Zanafa Publishing.

Al-Ali, W., Ameen, A., Isaac, O., Khalifa, G. S., \& Shibami, A. H. (2019). The mediating effect of job happiness on the relationship between job satisfaction and employee performance and turnover intentions: A case study on the oil and gas industry in the United Arab Emirates. Journal of Business and Retail Management Research, 13(4).

Amri, K. (2015). Pengaruh perilaku kepemimpinan dan motivasi dalam meningkatkan produktivitas kerja karyawan PT Bank Sinarmas Tbk cabang Banda Aceh. Jurnal Ekonomi Manajemen dan Bisnis, 3(1), 522-536.

Aruldoss, A., Kowalski, K. B., \& Parayitam, S. (2020). The relationship between quality of work life and work life balancemediating role of job stress, job satisfaction and job commitment: evidence from India. Journal of Advances in Management Research.

Basyir, M. (2020). Pengaruh Physical Evidence terhadap Loyalitas Nasabah Bank Syariah: Peran Kepuasan sebagai Variabel Pemediasi. Jurnal Ekonomi dan Manajemen Teknologi Vol, 4(2).

Bruggeman, B., Tondeur, J., Struyven, K., Pynoo, B., Garone, A., \& Vanslambrouck, S. (2021). Experts speaking: Crucial teacher attributes for implementing blended learning in higher education. The Internet and Higher Education, 48, 100772. 
Duha, T. (2020). Motivasi Untuk Kinerja. Deepublish.

Ekhsan, M. (2019). The influence job satisfaction and organizational commitment on employee turnover intention. Journal of Business, Management, \& Accounting, 1(1).

Farmiati, J., \& Ismail, I. (2021). Pengaruh Pengembangan Karir Bank Aceh Syariah. Jurnal EMT KITA, 5(1), 83-90.

Farrington, D. P. (2020). Human development and criminal careers (pp. 223-244). Routledge.

Geisler, M., Berthelsen, H., \& Muhonen, T. (2019). Retaining social workers: The role of quality of work and psychosocial safety climate for work engagement, job satisfaction, and organizational commitment. Human Service Organizations: Management, Leadership

Governance, 43(1), 1-15.

Idiegbeyan-Ose, J., Opeke, R., Aregbesola, A., Owolabi, S., \& Eyiolorunshe, T. A. (2019). Relationship between motivation and job satisfaction of staff in private university libraries, Nigeria. Academy of Strategic Management Journal, 18(1).

Irabor, I. E., \& Okolie, U. C. (2019). A review of employees' job satisfaction and its affect on their retention. Annals of Spiru Haret University. Economic Series, 19(2), 93114.

Jumaboyeva, J. S., \& Daminova, G. O. (2019). ROLE $\mathrm{OF}$ TEACHERS'MOTIVATION IN TEACHING. Bonpoсв r науки $u$ образования, (3), 84-88.

Malhotra, Y., \& Galletta, D. (2005). A multidimensional commitment model of volitional systems adoption and usage behavior. Journal of Management Information Systems, 22(1), 117-151.
Mathis, R. L., \& Jackson, J. H. (2006). Human resource management. Mineapolis/St. Paul.

Mulyasa, E., Mulyasana, D., Anwar, H., \& Kurniadi, B. (2020). The Effect Of Performance Accountability And Internal Control On Good Governance And Its Impact On Government Performance. PalArch's Journal of Archaeology of Egypt/Egyptology, 17(4), 379393.

Paais, M., \& PATTIRUHU, J. R. (2020). Effect of motivation, leadership, and organizational culture on satisfaction and employee performance. The Journal of Asian Finance, Economics, and Business, 7(8), 577-588.

Phuong, T. T. K., \& Vinh, T. T. (2020). Job satisfaction, employee loyalty and job performance in the hospitality industry: A moderated model. Asian Economic and Financial Review, 10(6), 698-713.

Priansa, Donni Juni. 2018. Perencanaan \& Pengembangan SDM. Bandung. Alfabeta.

Rizal, S. (2019). The Influence of Engagement in Decision Making, Assessment of Work Environment and Achievement Motivation on Employee Job Satisfaction of Free and Free Foreign Trade of Sabang Port (BPKS) of Aceh Province, Indonesia. International Journal of Research \& Review, 6 (2), 271-286.

Sarboini, S., \& Mariati, M. (2020). Pengaruh Kompensasi, Gaya Kepemimpinan dan Motivasi Kerja Terhadap Kinerja Pegawai pada Badan Arsip dan Perpustakaan Provinsi Aceh. Jurnal EMT KITA, 4(1), 110.

Sarboini, S., \& Yanti, S. (2018). Faktor-Faktor yang Mempengaruhi Produktivitas Kerja Pegawai Dinas Kebudayaan dan Pariwisata Aceh. Jurnal EMT KITA, 2(1), 38-46. 
Supardi. 2014. Kinerja Guru. Jakarta: PT Raja Grafindo Persada

Sutiana, D., \& Mulyasa, E. (2019). Manajemen Pembinaan Kinerja Guru Dalam Peningkatan Pembelajaran Mata Pelajaran Kejuruan. Kajian Manajemen Pendidikan, 2(2), 117-124.
TS, N. (2019). Development And Validation Of Job Satisfaction Scale For Different Sectors. International Journal for Quality Research, 13(1).

Udin Syaefudin Saud, Pengembangan Profesi Guru, (Bandung; Alfabeta, 2013). Cet. 6. 